\title{
Çocukların Meyve ve Sebze Tüketim Alışkanlığının Sosyoekonomik Durum İle İlişkisinin İncelenmesi
}

\author{
Dilek Arduzlar Kağan ${ }^{1 *}$, Ecenur Özkul ${ }^{2}$, Can Ergün ${ }^{3}$, Aylin Sam ${ }^{4}$, Nilüfer Şen ${ }^{5}$
}

\begin{abstract}
${ }^{1}$ Bahçeşehir Üniversitesi, Sağlık Bilimleri Fakültesi, Beslenme ve Diyetetik Bölümü, İstanbul, Türkiye, (https://orcid.org/0000-0001-8688-9039) ${ }^{2}$ Bahçeşehir Üniversitesi, Sağlık Bilimleri Fakültesi, Beslenme ve Diyetetik Bölümü, İstanbul, Türkiye (https://orcid.org/0000-0002-2651-0135) ${ }^{3}$ Bahçeşehir Üniversitesi, Sağlık Bilimleri Fakültesi, Beslenme ve Diyetetik Bölümü, İstanbul, Türkiye (https://orcid.org/0000-0001-5139-4407) ${ }^{4}$ Bahçeşehir Üniversitesi, Sağlık Bilimleri Fakültesi, Beslenme ve Diyetetik Bölümü, İstanbul, Türkiye (https://orcid.org/0000-0001-8538-1022) ${ }^{5}$ Bahçeşehir Üniversitesi, Sağlık Bilimleri Fakültesi, Beslenme ve Diyetetik Bölümü, İstanbul, Türkiye (https://orcid.org/0000-0002-6525-8841)
\end{abstract}

(İlk Geliş Tarihi 5 Ağustos 2019 ve Kabul Tarihi 1 Kasım 2019)

(DOI: 10.31590/ejosat.601896)

ATIF/REFERENCE: Arduzlar Kağan, D., Özkul, E., Ergün, C., Sam, A. \& Şen, N. (2019). Çocukların Meyve ve Sebze Tüketim Alışkanlığının Sosyoekonomik Durum İle İlişkisinin İncelenmesi. Avrupa Bilim ve Teknoloji Dergisi, (17), 570-580.

\begin{abstract}
$\ddot{O} \mathbf{z}$
Beslenme alışkanlıkları çevresel faktörler içerisinde çocukluk çağı obezitesine sebep olan en önemli etkenlerden birisidir. Yaşam boyu sürdürülen alışkanlıkların kazanıldığı bu dönemde doğru beslenme alışkanlıklarının kazanılması, ailenin beslenme bilgisi, tutumu, davranışları ve alım gücüyle doğrudan ilişkilidir. Meyve ve sebze tüketimi de doğru beslenme alışkanlıkları kazanılmasında anahtar rol oynayıcı faktörlerdendir. Bu çalışma; çocukluk çağında, meyve-sebze tüketim alışkanlığının incelenmesi ve değişen sosyoekonomik statütünün bu alışkanlığa olan etkisinin incelenmesi amacıyla araştırmacılar tarafından hazırlanan ve 2 bölümden oluşan anket formu kullanılarak 7-14 yaş arası 190 gönüllü katılımcı ile yürütülmüştür. Anket formunun ilk bölümünde bireylerin ve ebeveynlerinin sosyodemografik verilerini sorgulayan 9 adet soru bulunmaktadır. İkinci bölümde ise, katılımcıların meyve ve sebze tüketim sıklıkları, tüketim şekilleri ve sevilen meyve ve sebzeler sorgulanmıştır. Katılımcıların 7-11 yaş aralığında bulunan \%46,3'sı her gün, \%24,1'i haftada 3 gün sebze tükettiklerini belirtmiştir. Katılımcılardan 11-14 yaş grubunda olanların ise \%33,3'ü haftada 3 gün, $\% 24,8$ 'i ise her gün sebze tükettiklerini belirtmiştir. Sebze tüketim sıklığ ile aylık gelir düzeyi arasında ise anlamlı bir ilişki tespit edilmiştir $\left(\chi^{2}=17,21, \mathrm{p}<0.05\right)$. Gelir düzeyi daha düşük olan katılımcıların daha sık sebze tüketme eğilimde oldukları anlaşılmıştır. Meyve tüketimi ile gelir durumu arasında ise anlamlı bir ilişki bulunamamıştır ( $>0.05)$. Anne eğitim düzeyi incelendiğinde ise, ortaokul ve üzerine doğru ilerledikçe meyve sebze tüketim oranlarında yüzdesel artış saptanmıştır. Düşük ve orta sosyoekonomik (OSED) düzeye göre sebze tüketimi sırasıyla; çiğ (DSED: \%80,6, OSED: \%77,6), yağda kızartılmış şekilde (DSES: \%49,3, OSED: \%40,8), yüksek sosyoekonomik düzeydeki katılımcılarda ise; pişmiş soğuk yemek şeklinde $(\% 63,8)$, çiğ $(\% 55,3)$ olarak tüketildiği gözlenmiştir. Sağlıklı besinlerin doğru miktar ve şekillerde tüketilebilmesi için farklı ekonomik düzeylere uygun alternatifler yaratılarak verilecek beslenme eğitimleri çocuklarının sağlıklı beslenme alışkanlıkları kazanması için önemli bir adım olacaktır.
\end{abstract}

Anahtar Kelimeler: Meyve ve sebze, Beslenme alışkanlığı, Sosyoekonomik düzey

\section{Investigation of the Relationship between Fruit and Vegetable Consumption Habits of Children with Socioeconomic Situation}

\begin{abstract}
Nutritional habits are among the most important causes of childhood obesity in environmental factors. Lifelong acquisition of right eating habits maintained at the time of the gain of habits, family nutrition knowledge, attitudes, and behaviors are directly related to the purchasing power. Fruit and vegetable consumption is also a key factor in acquiring proper eating habits. This study; was conducted with 190 volunteer participants aged 7-14 using a 2-part questionnaire prepared by the researchers in order to investigate the consumption of fruit and vegetables in childhood and to examine the effect of changing socioeconomic status on this habit. In the first part of the questionnaire, there are 9 questions that question the sociodemographic data of individuals and their parents. In the second part, the frequency of consumption of fruits and vegetables, consumption patterns of the participants and the favorite fruits and
\end{abstract}

${ }^{1}$ Sorumlu Yazar: Dilek Arduzlar Kağan, Bahçeşehir Üniversitesi, Sağlık Bilimleri Fakültesi, Beslenme ve Diyetetik Bölümü, İstanbul, Türkiye, 0212381 9155 dilek.arduzlarkagan@hes.bau.edu.tr 
vegetables were questioned. Participants' who in the 7-11 age range $46.3 \%$ stated that they consume vegetables every day and $24.1 \%$ of them consume 3 days a week. $33.3 \%$ of the participants in the 11-14 age group stated that they consume vegetables 3 days a week and $24.8 \%$ every day. A significant relationship was found between the frequency of vegetable consumption and monthly income level. A significant correlation was found between the frequency of vegetable consumption and monthly income $(\chi 2=17.21, p<0.05)$. Participants with lower income levels tend to consume vegetables more frequently. There was no significant relationship between fruit consumption and income ( $p>0.05)$. When the education level of the mother was examined, it was found that the percentage of fruit and vegetable consumption increased as it progressed towards middle school and high up. Vegetable consumption according to low and middle socioeconomic (MSEL) levels were as follows; raw (LSEL: 80.6\%, MSEL: 77.6\%), fried in oil (LSEL: 49.3\%, MSEL: 40.8\%), high socioeconomic level participants; It was observed that it was consumed in the form of cooked cold food (63.8\%) and raw (55.3\%). Nutritional trainings will be an important step for children to gain healthy eating habits by creating alternatives suitable for different economic levels in order to consume healthy foods in the right amount and forms.

Keywords: Fruits and vegetables, Nutritional habits, Socioeconomic level

\section{Giriş}

Çocukluk çağı obezitesi gittikçe daha öncelikli bir halk sağlığı sorunu haline gelmektedir (Beaglehole vd. 2011). Çocukluk çağı obezitesi prevelansı ise klinik ve ekonomik sebeplerle dünya genelinde gittikçe artmaktadır (Kelly vd. 2008). ABD'de 1988-1994 yılları ve 2013-2014 arasında 2-19 yaş arası çocuk ve adölesanların obezite durumlarının değerlendirildiği bir çalışmada; çocukluk çağı obezitesi prevelansının \%5,8'den \%17,0’ye yükseldiği gösterilmiştir (Ogden vd. 2016). İngiltere'de 1994-2013 yılları arasında yapılan bir çalışmada ise 2-15 yaş arası çocuk ve adölesanlar arasında obezite görülme sıklığının her yıl \%0,8 artarak toplamda \% 8,1 artış gösterdiği bulunmuştur (Van vd. 2015). Bangladeş’te 6-15 yaş arasındaki okul çocuklarıyla yapılan bir araştırmada; çocukluk çağı obezitesi prevelansı \%9,7 bulunmuş bu verinin de Güney Doğu Asya'yla benzer olduğu gösterilmiştir (Jafar vd. 2008). Türkiye'de ise; son ulusal verilere göre, 6-18 yaş grubundaki obezite prevalansı \% 8,2 olarak bildirilmiştir (Sağlık Bakalığı 2010). Geçmişten günümüze kadar pek çok çalışmada yetişkinlik dönemindeki obezitenin çocukluk çağı obezitesinden kaynaklandığını, obez çocukların ileride obez yetişkinler olduğu gösterilmiştir (Serdula vd. 1993). Obezite için en önemli sebeplerden birisi ise besin seçimidir. Ömür boyu doğru ve yeterli besin seçimi ve çocukluk çağında oluşan alışkanlıklar ile yakından ilişkilidir (Van vd. 2015).

Dünya Sağlık Örgütü (DSÖ) tarafından 2012 yılında yayınlanmış raporda taze meyve ve sebze tüketiminin öneminden bahsedilmiştir. Raporda çocukluk ve adölesan dönemde kazandırılacak taze meyve ve sebze tüketim alışkanlığının çocukluk çağı obezitesini önlemesiyle birlikte ileri dönemde oluşabilecek obezite için de koruyucu faktör olacağından bahsedilmiştir (WHO 2012). Türkiye Beslenme Rehberi (TÜBER) 2015 raporuna göre; yaşa ve cinsiyete göre değişmesi gerekmekle birlikte sebze ve meyve tüketiminin günlük 2,5 ile 7 porsiyon arasında olması gerektiği bildirilmiştir (Sağlık Bakanlığı 2015).

Çocuklara sağlıklı beslenme alışkanlıkları kazandırmak ise ebeveynin bilinci ve sosyoekonomik düzeyi ile (SED) doğrudan ilişkilidir. Sosyoekonomik düzeye göre çocukluk çağı obezitesi görülme sıklığının değişim göstereceği çalışmalarda ileri sürülmüştür. Konu ile ilgili yapılan çalışmalar da; obezite görülme sıklığının sanayileşmiş ülkelerde düşük sosyoekonomik düzeyde (DSED) daha fazla görülürken, gelişmekte olan ülkelerde ise yüksek sosyoekonomik düzeyde (YSED) daha fazla görüldüğünü göstermiştir. Gelişmekte olan ülkelerde yükselen sosyoekonomik düzey ile fast food tüketiminin artıp taze meyve sebze tüketiminin azaltılması ve gelişmiş ülkelerde ise artan ebeveyn bilinci sonucu doğru beslenme alışkanlıklarının çocuklara kazandırılmasının bu farklılığın sebeplerinden olabileceği düşünülmüştür (Glasper 2010, Chen vd. 2011). Türkiye'de ise obezite prevalansının sosyoekonomik düzey ile doğru orantılı olarak arttığı gösterilmiştir (Baysal 2011). Ancak farklı sosyoekonomik düzeydeki çocuklarda çocukluk çağı obezitesi ve doğru besin tercihleri üzerine yapılmış çalışmalar sınırlı kalmıştır.

$\mathrm{Bu}$ çalışma; ömür boyu sürdürülecek alışkanlıkların kazanıldığı çocukluk çağında, anahtar noktalardan birisi sayılabilecek taze meyve ve sebze tüketim alışkanlığının yaş grubu ve cinsiyete göre incelenmesi, tüketmeme nedenlerinin belirlenmesi, değişen sosyoekonomik statütünün bu alışkanlığa olan etkisinin incelenmesi amacıyla yapılmıştır.

\section{Materyal ve Metot}

\section{1. Çalışma alanı ve tarihi}

Çalışma Şubat- Mart -Nisan tarihleri arasında İstanbul İlinde yaşayan farklı sosyoekonomik düzeydeki yaşları 7-14 arasında olan 190 öğrenci üzerinde tamamen gönüllülük esasına dayalı olarak yüz yüze anket yöntemiyle planlanıp yürütülmüştür.

\subsection{Anket formu}

Çalışmada kullanılan anket çalışmacılar tarafından planlanmıştır. Form iki bölümden oluşmaktadır. İlk bölümde sosyoekonomik durumu ölçen ailelere ilişkin birey sayısı, eğitim durumu, meslek ve aylık gelirlerine yönelik 9 soru bulunurken, ikinci bölümde ise sebze meyve tüketim alışkanlığını belirlemeyi hedefleyen sebze-meyve tüketim sıklığı, meyve-sebze tercihleri, meyve-sebze tanıyıp tanımama, severek tüketilen ve tüketilmeyen, bir günlük sebze-meyve tüketim kayıtlarını içeren 11 soru bulunmaktadır. 


\section{3.İstatistiksel Analiz}

Araştırmanın amacı doğrultusunda, toplanan veriler yüzde, frekans hesaplamaları ve Ki-kare testi kullanılarak SPSS 22.0 (Statistical Package for the Social Sciences) paket programında analiz edilmiştir. Analiz sonuçları $\% 95$ güven düzeyinde ele alınmış ve p $<0,05$ değerleri istatistiksel olarak anlamlı kabul edilmiştir.

\section{Araştırma Sonuçları ve Tartışma}

\subsection{Araştırma sonuçları}

Çocukluk döneminde ve adölesan dönemde edinilen beslenme davranışları, yaşam boyu sürdürülebilecek beslenme alışkanlıklara dönüşmektedir (Ahmadi vd. 2014). Büyüme ve gelişmenin hızlandığı, öğrenme ve kavrama işlevlerinin önem kazandığı okul çağında ise beslenmenin önemi daha da artmaktadır (Şimşek vd. 2009). Antioksidanlar, lif, vitaminler ve mineralleri içermesi açısından sebze ve meyveler beslenmenin önemli unsurlarıdır. Sebze meyve tüketimindeki artışın diyet kalitesini artırdığ çalışmalarda belirtilmiştir (Thompson vd. 2016). Rachel ve Sinley' in (2016) yaptığı çalışmada meyve ve sebze tüketiminin yetersiz olması çocuklarda obezite ile ilişkilendirilmiştir. Çalışmamızda İstanbul ilinde yaşayan 190 çocuk ve adölesan dönemdeki katılımcı ile gerçekleştirilmiştir Sosyo demografik bilgiler Tablo 1'de verilmiştir. Tablo 1'e göre; 190 katılımcının \%30 ' u 7-10 yaş arasında, \%70 'i ise 11-14 yaş aralığındadır. Katılımcıların \% 54,7’ si kız, \% 45,3 ‘ü erkektir. Gelir durumuna göre ise katılımc1lar, \% 39,4 oranında 2000- 4000 TL arası, \%36,2 oranında 2000 TL ve altı gelir düzeyine, \% 24,4 oranında ise 4000 TL ve üzeri gelir seviyesine sahiptir.

Tablo 1. Sosyodemografik Veriler

\begin{tabular}{|c|c|c|c|c|}
\hline Sosyodemografik Veriler & & & & \\
\hline & & $\begin{array}{c}\text { Frekans } \\
\text { (n) }\end{array}$ & $\begin{array}{c}\text { Yüzde } \\
(\%)\end{array}$ & $\begin{array}{c}\text { Toplam } \\
\text { Kişi } \\
\text { Sayısı }\end{array}$ \\
\hline \multirow{2}{*}{ Yaş } & 7-10 yaş & 57 & 30 & \multirow{2}{*}{190} \\
\hline & 11-14 yaş & 133 & 70 & \\
\hline \multirow{2}{*}{ Cinsiyet } & Kız & 104 & 54,7 & \multirow{2}{*}{190} \\
\hline & Erkek & 86 & 45,3 & \\
\hline \multirow{3}{*}{ Aylık gelir düzeyi } & 2000 TL altı & 67 & 36,2 & \multirow{3}{*}{185} \\
\hline & $2000-4000 \mathrm{TL}$ & 73 & 39,4 & \\
\hline & 4000 TL ve üzeri & 45 & 24,4 & \\
\hline
\end{tabular}


European Journal of Science and Technology

Tablo 2. Sebze ve Meyve Tüketim Siklıklarl

\begin{tabular}{|c|c|c|c|c|c|c|c|c|c|}
\hline \multirow{2}{*}{\multicolumn{3}{|c|}{$\begin{array}{c}\text { Sebze ve Meyve Tüketim } \\
\text { Sıklıkları }\end{array}$}} & \multicolumn{6}{|c|}{ Ne sıklıkla sebze tüketirsiniz? } & \multirow{3}{*}{$\begin{array}{c}\text { Toplam } \\
54\end{array}$} \\
\hline & & & \multirow{2}{*}{$\begin{array}{c}\text { Her gün } \\
25\end{array}$} & \multirow{2}{*}{$\begin{array}{c}\text { Haftada } \\
\mathbf{3} \\
13 \\
\end{array}$} & \multirow{2}{*}{$\begin{array}{c}\text { Haftada } \\
\mathbf{1} \\
8 \\
\end{array}$} & \multirow{2}{*}{$\begin{array}{c}\begin{array}{c}\text { Haftada } \\
\mathbf{2}\end{array} \\
6\end{array}$} & \multirow{2}{*}{$\begin{array}{c}\begin{array}{c}\text { On beş } \\
\text { günde }\end{array} \\
1 \\
\end{array}$} & \multirow{2}{*}{$\frac{\text { Ayda } 1}{1}$} & \\
\hline \multirow{4}{*}{ Yaş } & \multirow{2}{*}{$7-10$ yaş } & $\mathrm{n}$ & & & & & & & \\
\hline & & $\%$ & $46,3 \%$ & $24,1 \%$ & $14,8 \%$ & $11,1 \%$ & $1,9 \%$ & $1,9 \%$ & $100,0 \%$ \\
\hline & \multirow{2}{*}{$\begin{array}{c}11-14 \\
\text { yaş }\end{array}$} & $\mathbf{n}$ & 26 & 35 & 18 & 18 & 6 & 2 & 105 \\
\hline & & $\%$ & $24,8 \%$ & $33,3 \%$ & $17,1 \%$ & $17,1 \%$ & $5,7 \%$ & $1,9 \%$ & $100,0 \%$ \\
\hline \multirow{2}{*}{\multicolumn{2}{|c|}{ Toplam }} & $\mathbf{n}$ & 51 & 48 & 26 & 24 & 7 & 3 & 159 \\
\hline & & $\%$ & $32,1 \%$ & $30,2 \%$ & $16,4 \%$ & $15,1 \%$ & $4,4 \%$ & $1,9 \%$ & $100,0 \%$ \\
\hline & & & \multicolumn{6}{|c|}{ Ne sıklıkla meyve tüketirsiniz? } & \\
\hline & & & Her gün & $\begin{array}{l}\text { Haftada } \\
\quad 3\end{array}$ & $\begin{array}{c}\text { Haftada } \\
1\end{array}$ & $\begin{array}{l}\text { Haftada } \\
2\end{array}$ & $\begin{array}{l}\text { On bes } \\
\text { günde }\end{array}$ & Ayda 1 & Toplam \\
\hline \multirow{4}{*}{ Yaş } & \multirow{2}{*}{$7-10$ yaş } & $\mathbf{n}$ & 37 & 10 & 8 & 1 & 0 & 1 & 57 \\
\hline & & $\%$ & $64,9 \%$ & $17,5 \%$ & $14,0 \%$ & $1,8 \%$ & $0,0 \%$ & $1,8 \%$ & $100,0 \%$ \\
\hline & \multirow{2}{*}{$\begin{array}{c}11-14 \\
\text { yaş }\end{array}$} & $\mathbf{n}$ & 62 & 41 & 13 & 10 & 2 & 0 & 128 \\
\hline & & $\%$ & $48,4 \%$ & $32,0 \%$ & $10,2 \%$ & $7,8 \%$ & $1,6 \%$ & $0,0 \%$ & $100,0 \%$ \\
\hline \multirow{2}{*}{\multicolumn{2}{|c|}{ Toplam }} & $\mathbf{n}$ & 99 & 51 & 21 & 11 & 2 & 1 & 185 \\
\hline & & $\%$ & $53,5 \%$ & $27,6 \%$ & $11,4 \%$ & $5,9 \%$ & $1,1 \%$ &, $5 \%$ & $100,0 \%$ \\
\hline & & & \multicolumn{6}{|c|}{ Sebzeleri ne sıklıkla tüketirsiniz? } & \\
\hline & & & Her gün & $\begin{array}{l}\text { Haftada } \\
\quad 3 \\
\end{array}$ & $\begin{array}{c}\text { Haftada } \\
1\end{array}$ & $\begin{array}{c}\text { Haftada } \\
2\end{array}$ & $\begin{array}{l}\text { On bes } \\
\text { günde }\end{array}$ & Ayda 1 & Toplam \\
\hline \multirow{4}{*}{ Cinsiyet } & \multirow{2}{*}{ Kız } & $\mathrm{n}$ & 18 & 29 & 15 & 17 & 3 & 3 & 85 \\
\hline & & $\%$ & $21,2 \%$ & $34,1 \%$ & $17,6 \%$ & $20,0 \%$ & $3,5 \%$ & $3,5 \%$ & $100,0 \%$ \\
\hline & \multirow{2}{*}{ Erkek } & $\mathrm{n}$ & 33 & 19 & 11 & 7 & 4 & 0 & 74 \\
\hline & & $\%$ & $44,6 \%$ & $25,7 \%$ & $14,9 \%$ & $9,5 \%$ & $5,4 \%$ & $0,0 \%$ & $100,0 \%$ \\
\hline \multirow{2}{*}{\multicolumn{2}{|c|}{ Toplam }} & $\mathrm{n}$ & 51 & 48 & 26 & 24 & 7 & 3 & 159 \\
\hline & & $\%$ & $32,1 \%$ & $30,2 \%$ & $16,4 \%$ & $15,1 \%$ & $4,4 \%$ & $1,9 \%$ & $100,0 \%$ \\
\hline & & & \multicolumn{6}{|c|}{ Ne siklıkla meyve tüketirsiniz? } & \\
\hline & & & Her gün & $\begin{array}{l}\text { Haftada } \\
3\end{array}$ & $\begin{array}{l}\text { Haftada } \\
1\end{array}$ & $\begin{array}{l}\text { Haftada } \\
2\end{array}$ & $\begin{array}{l}\text { On beş } \\
\text { günde }\end{array}$ & Ayda 1 & Toplam \\
\hline \multirow{4}{*}{ Cinsiyet } & \multirow{2}{*}{ Kız } & $\mathrm{n}$ & 51 & 35 & 11 & 5 & 0 & 1 & 103 \\
\hline & & $\%$ & $49,5 \%$ & $34,0 \%$ & $10,7 \%$ & $4,9 \%$ & $0,0 \%$ & $1,0 \%$ & $100,0 \%$ \\
\hline & \multirow{2}{*}{ Erkek } & $\mathrm{n}$ & 48 & 16 & 10 & 6 & 2 & 0 & 82 \\
\hline & & $\%$ & $58,5 \%$ & $19,5 \%$ & $12,2 \%$ & $7,3 \%$ & $2,4 \%$ & $0,0 \%$ & $100,0 \%$ \\
\hline \multirow{2}{*}{\multicolumn{2}{|c|}{ Toplam }} & $\mathrm{n}$ & 99 & 51 & 21 & 11 & 2 & 1 & 185 \\
\hline & & $\%$ & $53,5 \%$ & $27,6 \%$ & $11,4 \%$ & $5,9 \%$ & $1,1 \%$ &, $5 \%$ & $100,0 \%$ \\
\hline
\end{tabular}

Sebze meyve tüketim sıklığı yaş gruplarına göre farklılık gösterebilmektedir (Yazman, 2016). Mevcut çalışmalar göstermiştir ki çocukların yaşları büyüdükçe sebze tüketimleri belirgin şekilde azalmaktadır (Larson vd., 2009). Birleşik Krallık Ulusal Beslenme Anketi’ne göre katılımcıların yaşları ilerledikçe sebze meyve tüketimlerinin azaldığı ve ergenlik döneminde en düşük seviyeye ulaştığı belirlenmiştir (Albani vd., 2017). Almanya'da yapılan çalışmada ise 7-10 yaş arası çocuklarda diğer yaş grubundakilere göre meyve tüketimi kıyaslandığında gruplar arasında anlamlı fark elde edilmiştir $(\mathrm{p}<0,05)$ (Borrmann ve Mensink, 2015). Polonya'da 9 yaşındaki çocuklarla gerçekleştirilen çalışmada yaşları büyüdükçe çocukların sebze meyve tüketiminin azaldığı belirlenmiştir (Wolnıcka vd., 2015). Çalışma grubumuzda da Tablo 2'de belirtildiği gibi mevcut çalışmaları destekleyen sonuçlar ortaya çıkmıştır. 7-10 yaş arası katılımcıların sebze meyve tüketimi, 11-14 yaş arası katılımcıların sebze meyve tüketiminden iki cinsiyette de daha yüksek çıkmıştır. Grubun 7-10 yaşındaki katılımcılarının büyük bir kısmı "her gün" (\%46,3) ve "haftada 3 gün" (\%24,1) sebze tükettiklerini belirtmiştir. 11-14 yaş grubunda da benzer şekilde katılımcıların büyük bir oranı, "haftada 3 gün" $(\% 33,3)$ ve "her gün" $(\% 24,8)$ sebze tükettiklerini belirtmiştir. Cinsiyet olarak en yüksek oranlar değerlendirildiğinde, erkeklerin $\% 58,5^{\prime}$ i sı kızların ise, $\% 49,5$ hergün meyve yediğini belirtirken, sebze tüketimi cinsiyete göre gözlemlendiğinde ise,erkeklerin \%44,6' sı hergün sebze tükettiklerini belirtirken, kızların \%34,1'i haftada 3 tükettiklerini bildirmişlerdir. Sebze-meyve tüketimi de cinsiyete göre farklılık göstermektedir (Pedersen, 2011, Yazman, 2016). Yapılan çalışmalar kız çocuklarının, erkeklerden daha fazla ve sık sebze meyve tükettiğini göstermiştir (Bere, 2007, Von, 2002). Avrupa'da 33 ülkede yapılan çalışmada da kız çocuklarının, erkeklere kıyasla daha fazla sebze meyve tükettiği belirlenmiştir (Diethelm, 2012, Vereecken, 2015). Ülkemizde de literatürü destekleyen çalışmalar mevcuttur (Yazman 2016). Gerçekleştirilen çalışmada ise diğer çalışmaların tersine erkek katılımcıların sebze meyve tüketim sıklı̆̆ı kız katılımcılara göre daha yüksek bulunmuş̧ur (E: \%58,5, K: \%49,5). Literatürde ki çalışmaların daha büyük katılımcı ile gerçekleştirilmiş olmasının ve çalışma grubumuzun çoğunluğunun erkek olmasının bu sonucu etkileyebileceği düşünülmüştür. 
Tablo 3. Katılımclların Sebze ve Meyve Tüketmeme Nedenleri

\begin{tabular}{|c|c|c|c|}
\hline $\begin{array}{l}\text { Sebze ve Meyve } \\
\text { Tüketmeme Nedenleri }\end{array}$ & & $\begin{array}{l}\text { Frekans } \\
\text { (n) }\end{array}$ & $\begin{array}{c}\text { Yüzde } \\
(\%)\end{array}$ \\
\hline \multirow{5}{*}{ Sebze tüketmeme nedeni } & Besin alerjim var & 2 & 1,1 \\
\hline & Kokusunu tadını sevmiyorum & 27 & 14,2 \\
\hline & $\begin{array}{l}\text { Rengini, şeklini } \\
\text { beğenmiyorum }\end{array}$ & 15 & 7,9 \\
\hline & Yeme alışkanlığım yok & 17 & 8,9 \\
\hline & $\begin{array}{l}\text { Annem, babam, kardeşim de } \\
\text { yemiyor }\end{array}$ & 10 & 5,3 \\
\hline \multirow{4}{*}{ Meyve tüketmeme nedeni } & Kokusunu tadını sevmiyorum & 3 & 1,6 \\
\hline & $\begin{array}{l}\text { Rengini, şeklini } \\
\text { beğenmiyorum }\end{array}$ & 2 & 1,1 \\
\hline & Yeme alışkanlığım yok & 4 & 2,1 \\
\hline & $\begin{array}{l}\text { Annem, babam, kardeşim de } \\
\text { yemiyor }\end{array}$ & 1 &, 5 \\
\hline
\end{tabular}

Bireylerin besin seçimini etkileyen başlıca faktörler; açlık, besinleri yemeye karşı duyulan istek, besinlerin lezzeti, aile, besinlerin bulunabilirliği besin seçimlerini önemli ölçüde etkileyen faktörlerdendir (Kabaran ve Mercanlıgil 2013, Larson vd. 2012). Meyve ve sebze tüketim alışkanlığı ile ilgili çalışmalar ise; ailenin meyve ve sebze tüketim alışkanlıklarının, besinlerin bulunabilirliği ve en önemlisi tadından hoşlanmanın çocukların meyve ve sebze tüketiminde en önemli belirleyiciler olduğunu göstermiş̧ir (Liem, 2006, Gibson, 1998). Tablo 3 'te katılımcıların sebze ve meyve tüketmeme sebepleri verilmiştir. Katılımcılar; sebze tüketmeme nedeni olarak $\% 14,2$ oranında kokusunu tadını sevmiyorum, $\% 8,9$ oranında yeme alışkanlığım yok, $\% 7,9$ oranında rengini, şeklini beğenmiyorum, $\% 5,3$ oranında annem, babam, kardeşim de yemiyor ve $\% 1,1$ oranında besin alerjim var olarak bildirmişlerdir. Katılımcıların meyve tüketmeme sebebi olarak ise, yeme alışkanlı̆̆ım yok $(\% 2,1)$, kokusunu tadını sevmiyorum $(\% 1,6)$, rengini, şeklini beğenmiyorum $(\% 1,1)$ ve annem, babam, kardeşim de yemiyor $(\% 0,5)$ cevaplarını vermişlerdir. Meyve tüketim sıklıkları incelendiğinde ise; 7-10 yaş grubunda bulunan katılımcıların büyük bir kısmı "her gün" (\%64,9) meyve tükettiklerini belirtmiştir. Diğer yaş grubu olan 11-14 yaş grubunda da benzer şekilde katılımcıların büyük bir oranı, "her gün" (\%48,4) ve "haftada 3 gün" (\%32) meyve tükettiklerini belirtmiştir. Meyve ve sebze tüketimini engelleyen faktörlerin belirlenmesi amacıyla Haynes' in (2013) yaptığı çalışmada; fiyat, ulaşım, kalite, ulaşılabilen besinlerin çeşitliliği ve değişen toplumsal modelin meyve ve sebzeye ulaşmada engel oluşturduğu belirtilmiştir. Blanchette'nin (2005) 6-12 yaş aralığındaki katılımcılar ile yaptığı çalışmada meyve ve sebze tüketiminde en belirleyici faktör besinin erişebilir olmasıdır. Tablo 3 te belirtildiği üzere yapılan çalışmada; sebze tüketmeyen çocuklarda kokusunu, tadını sevmiyor olmaları $(\% 14,2)$ tüketmeme sebeplerinin en belirleyicisidir. Araştırma grubumuzdaki meyve tüketmeyen çocuklarda yeme alışkanlıklarının olmaması $(\% 2,1)$ tüketmeme sebeplerinin en belirleyicisidir. Katılımcıların \% 5.3'ü aile bireyleri sebze tüketmediği için kendisinin de tüketmediğini belirtmiştir. Ailelerin besin seçimi ile ilgili davranış ve tutumlarının, çocuklarının besin tüketimlerinde etkili olduğu görülmüştür. Ebeveynlerin meyve ve sebze tüketmelerinin, çocuklarına da tüketim alışkanlıklarını kazandırmasının etkili yöntemlerinden biri olduğu savunulabiilir. Benzer olarak; Perikkou ve ark. (2013) Kıbrıs'ta 218 ilkokul 3. sınıf öğrencisi ile yaptıkları çalışmada daha önce beğenilmeyen bir sebzeyi katılımcıların ebeveynlerinin tüketmesi, çocukların bu sebzeyi sevmelerini ve tüketmelerini sağladığı tespit edilmiştir. 
European Journal of Science and Technology

\begin{tabular}{|c|c|c|c|c|c|c|c|c|c|}
\hline & & & \multicolumn{4}{|c|}{ Ne sıklıkla sebze tüketirsiniz? } & \multirow[b]{2}{*}{ Toplam } & \multirow[b]{2}{*}{$\chi^{2}$} & \multirow[b]{2}{*}{$\mathbf{p}$} \\
\hline & & & Her gün & $\begin{array}{c}\text { Haftada } \\
\quad \mathbf{3}\end{array}$ & $\begin{array}{c}\text { Haftada } \\
\quad 1\end{array}$ & $\begin{array}{c}\text { Haftada } \\
2 \text { ve } \\
\text { daha } \\
\text { fazla }\end{array}$ & & & \\
\hline \multirow{6}{*}{$\begin{array}{l}\text { Aylık } \\
\text { gelir } \\
\text { düzeyi }\end{array}$} & \multirow{2}{*}{$\begin{array}{c}2000 \mathrm{TL} \\
\text { altı }\end{array}$} & $\mathbf{n}$ & 27 & 13 & 11 & 9 & 60 & \multirow{8}{*}{17,21} & \multirow{8}{*}{, 01} \\
\hline & & $\%$ & $45,0 \%$ & $21,7 \%$ & $18,3 \%$ & $15,0 \%$ & $100,0 \%$ & & \\
\hline & \multirow{2}{*}{$\begin{array}{r}2000- \\
4000 \mathrm{TL} \\
\end{array}$} & $\mathbf{n}$ & 18 & 17 & 12 & 18 & 65 & & \\
\hline & & $\%$ & $27,7 \%$ & $26,2 \%$ & $18,5 \%$ & $27,7 \%$ & $100,0 \%$ & & \\
\hline & \multirow{2}{*}{$\begin{array}{l}4000 \mathrm{TL} \\
\text { ve üzeri }\end{array}$} & $\mathbf{n}$ & 6 & 18 & 3 & 7 & 34 & & \\
\hline & & $\%$ & $17,6 \%$ & $52,9 \%$ & $8,8 \%$ & $20,6 \%$ & $100,0 \%$ & & \\
\hline \multirow{2}{*}{\multicolumn{2}{|c|}{ Toplam }} & $\mathbf{n}$ & 51 & 48 & 26 & 34 & 159 & & \\
\hline & & $\%$ & $32,1 \%$ & $30,2 \%$ & $16,4 \%$ & $21,4 \%$ & $100,0 \%$ & & \\
\hline & & & \multicolumn{4}{|c|}{ Ne sıklıkla meyve tüketirsiniz? } & & \multirow[b]{2}{*}{$\chi^{2}$} & \multirow[b]{2}{*}{$\mathbf{p}$} \\
\hline & & & Her gün & $\begin{array}{c}\text { Haftada } \\
\mathbf{3}\end{array}$ & $\begin{array}{c}\text { Haftada } \\
1\end{array}$ & $\begin{array}{c}\text { Haftada } \\
2 \text { ve } \\
\text { daha } \\
\text { fazla } \\
\end{array}$ & Toplam & & \\
\hline \multirow{6}{*}{$\begin{array}{l}\text { Ayllk } \\
\text { gelir } \\
\text { düzeyi }\end{array}$} & $2000 \mathrm{TL}$ & $\mathbf{n}$ & 38 & 11 & 11 & 7 & 67 & \multirow{8}{*}{9,86} & \multirow{8}{*}{0,13} \\
\hline & altı & $\%$ & $56,7 \%$ & $16,4 \%$ & $16,4 \%$ & $10,4 \%$ & $100,0 \%$ & & \\
\hline & & $\mathbf{n}$ & 40 & 23 & 5 & 5 & 73 & & \\
\hline & $4000 \mathrm{TL}$ & $\%$ & $54,8 \%$ & $31,5 \%$ & $6,8 \%$ & $6,8 \%$ & $100,0 \%$ & & \\
\hline & $4000 \mathrm{TL}$ & $\mathbf{n}$ & 21 & 17 & 5 & 2 & 45 & & \\
\hline & ve üzeri & $\%$ & $46,7 \%$ & $37,8 \%$ & $11,1 \%$ & $4,4 \%$ & $100,0 \%$ & & \\
\hline \multirow{2}{*}{\multicolumn{2}{|c|}{ Toplam }} & $\mathbf{n}$ & 99 & 51 & 21 & 14 & 185 & & \\
\hline & & $\%$ & $53,5 \%$ & $27,6 \%$ & $11,4 \%$ & $7,6 \%$ & $100,0 \%$ & & \\
\hline
\end{tabular}

Besin seçiminin diğer bir belirleyicisi ise; ailelerin sosyoekonomik durumunun besinlere ulaşımına etkisidir (Ding vd. 2012, Han vd. 2010, Bere vd. 2008, Neumark vd. 2008, Molaison vd. 2005). Bireylerin meyve ve sebzeleri tüketim sıklıkları; bireysel tercihlerinden çok içinde bulunulan sosyoekonomik, demografik ve kültürel çevrenin etrafinda şekillenmektedir (Aydın, 2011). Tablo 4'te sosyoekonomik düzey ile sebze tüketim sıklığı karşılaştırılmıştır. Sonuçlara göre; aylık geliri 2000 TL altı olan katılımcıların \%45'i her gün, $\% 21,7$ 'si haftada $3, \% 18,3$ 'ü haftada 1 ve $\% 15$ 'i haftada 2 ve daha az sebze tüketmektedir. Gelir düzeyi $2000-4000$ TL olan katılımcıların \%27,7'si her gün, \%26,2'si haftada 3,\%18,5'i haftada 1 ve $\% 27,7$ 'si haftada 2 ve daha az sebze tükettiklerini bildirmişlerdir. Gelir düzeyi 4000 TL ve üzeri olan katılımcıların $\% 17,6$ 'sının her gün, $\% 52,9$ 'unun haftada 3, \%8,8'inin haftada 1 ve $\% 20,6$ 'sının ise haftada 2 ve daha az sebze tükettiği tespit edilmiştir. Sebze tüketim sıklığı ile aylık gelir düzeyi arasında anlamlı bir ilişki gözlemlenememiştir $\left(\chi^{2}=17,21, p<0,05\right)$. Gelir düzeyi daha düşük olan katılımcıların daha sık sebze tüketme eğilimde oldukları anlaşılmışır. Sosyoekonomik düzey ile meyve tüketim sıklığı karşılaştırıldığında; gelir düzeyi 2000 TL altı olan katılımcıların \%56.7'si her gün, \%16,4'ü haftada 3, \%16,4'ü haftada 1 ve \%10,4'ü haftada 2 ve daha az meyve tüketmektedir. Gelir düzeyi 2000-4000 TL olan katılımcıların \%54,8'inin her gün, $\% 31,5^{\prime}$ 'inin haftada 3, \%6,8'inin haftada 1 ve $\% 6,8^{\prime}$ 'inin haftada 2 ve daha az meyve tükettiği tespit edilmiştir. Gelir düzeyi 4000 TL ve üzeri olan katılımcıların \%46,7'si her gün, \%37,8'i haftada 3, \%11,1'i haftada 1 ve $\% 4,4$ 'ü ise haftada 2 ve daha az meyve tüketmektedir. Meyve tüketim sıklığı ile aylık gelir düzeyi arasında anlamlı bir ilişki bulunamamıştır $\left(\chi^{2}=9,86, p>0,05\right)$. Yazman (2016)' in çalışmasında YSED'deki çocuklarda DSED'dekilere kıyasla sebze meyve tüketimi daha yüksek bulunmuştur. Benzer bir şekilde Uçar ve Çakıroğlu'nun (2012) çalışmasında; düşük, orta ve yüksek SED' den katılımcılar ile yapılan çalışmada en yüksek meyve tüketiminin orta sosyoekonomik düzeyde, en az ise düşük sosyoekonomik düzeyde görüldüğü belirlenmiştir. Borrmann ve Mensink' in (2015) çalışmasında sosyoekonomik düzeyi düşük ailelerin çocuklarının beslenme alışkanlıkları incelendiğinde sebze meyve tüketimlerinin düşük ve sağllksız bir diyet ile beslendikleri görülmüşsür. Bunun en önemli nedeninin sebze meyvelerin fiyatlarının yüksek oluşu ve ailelerin alım gücü olmamasından kaynaklandığı tespit edilmiştir. Amerika'da Hughes (2012) ve Dubowitz (2008)' in yaptı̆̆ı çalışmalarında da literatürü destekler biçimde DSED' de meyve tüketimi daha düşük bulunmuştur. Türkiye İstatistik Kurumu'nun yaptığı "Hane halkı tüketim harcamaları" anketinin sonucuna göre sosyoekonomik durumu düşük ailelerde en çok tüketilen gıda grupları tahıl ürünleri ve sebze meyve olduğu belirlenmiştir (Aydın, 2011). Yapılan çalışmada Tablo 4'te gösterildiği üzere meyve tüketip tüketmeme durumu ve meyve tüketim sıklı̆̆ ile SED arasında anlamlı bir ilişki bulunmamıştır. Sebze sebze tüketim sıklığı ile SED ise ilişkili bulunmuştur $(\chi 2=5,94, \mathrm{p} \leq 0,05)$. DSED'deki katılımcılarda sebze tüketimi $(\% 89,6)$ ve sebze tüketim sıklığı (\%45’i her gün) diğer gruplardan daha yüksek bulunmuştur. Ülkemizde; sosyoekonomik düzeyi düşük hanelerin beslenmesi büyük ölçüde bitkisel besinlere dayalı olduğu daha önce yapılan çalışmalarda bildirilmiştir (Baysal 2011). Ülkeler arası görülen bu farklılı̆̆ın; iklim değişikliğine bağlı olarak sebze ve meyve satış fiyatlarının değişmesi ile ilişkilendirilebilir. Besinleri satın alım gücünün tüketimi belirleyen önemli bir sebep olduğu unutulmamalıdır. 


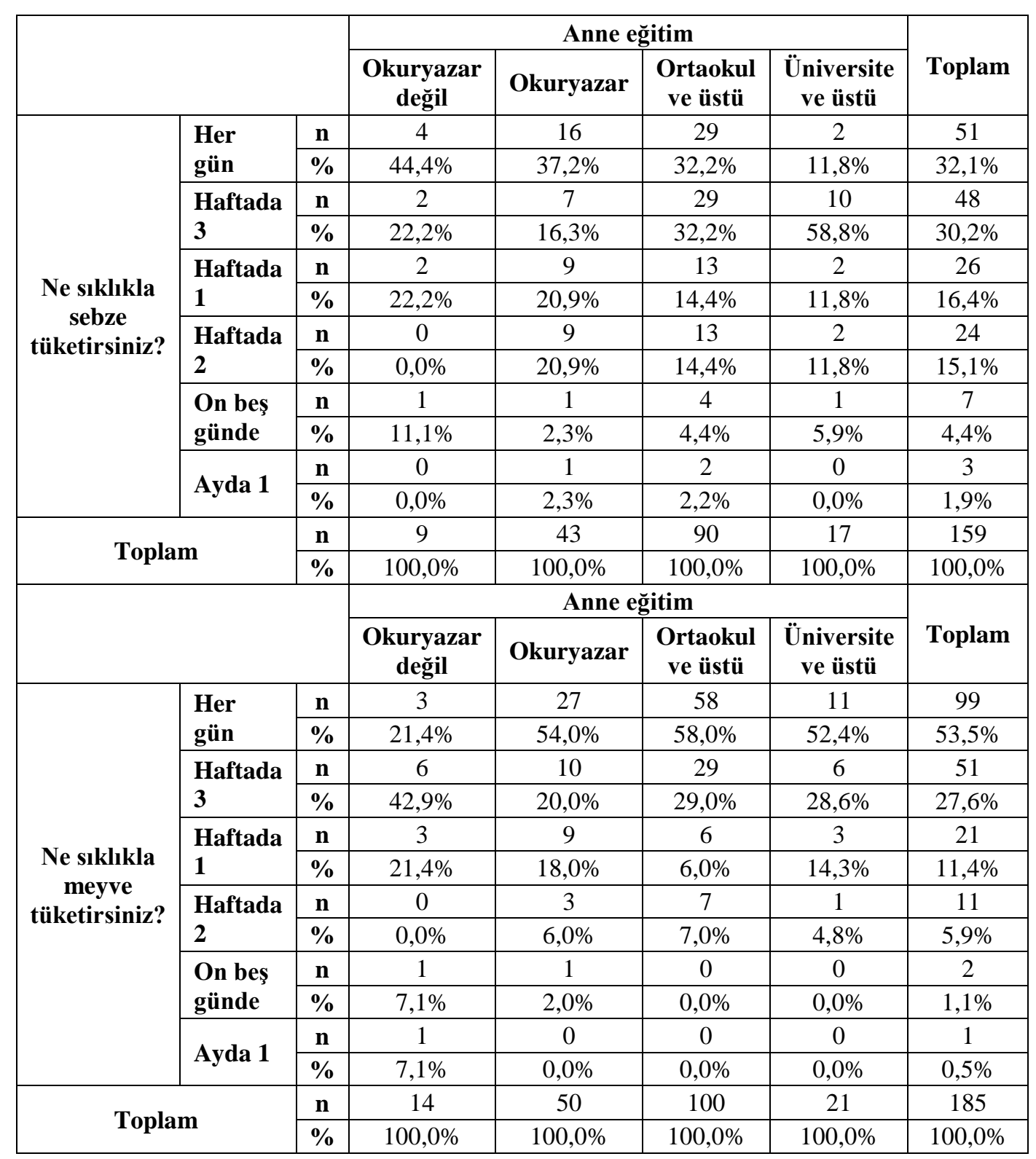

Ülkemizde okul çağı çocuklarında meyve ve sebze tüketiminin sorgulandığı Türkiye'de Okul Çağı Çocuklarında (2011) (6-10 Yaş Grubu) Büyümenin İzlenmesi çalışmasına göre her gün sebze ve meyve tüketen çocukların oranı sırasıyla \%25.8 ve \%31.1 olarak bulunmuştur. Yapılan çalışma ile ilgili, Tablo 5'de annenin eğitim düzeyi ile sebze tüketimi ilişkisi verilmiştir. Annesi okuryazar olmayan katılımcılar sırasıyla, her gün $(\% 44,4)$, haftada $3(\% 22,2)$ ve haftada $1(\% 22,2)$ sebze tükettiğini belirtmişlerdir. Annesi okuryazar olan katılımcılar ise $\% 37,2$ oranında her gün olmak üzere, haftada $3(\% 16,3)$, haftada $1(\% 14,4)$ ve haftada $2(\% 14,4)$ sebze tükettiğini bildirmişlerdir. Annesi ortaokul ve üstü eğitim düzeyinde bulunan katılımcılar aynı oranda her gün $(\% 32,2)$ ve haftada 3 $(\% 32,2)$ sebze tükettiği tespit edilmiştir. Annesi lisans ve üstü eğitim düzeyinde bulunan katılımcıların büyük bir oranı ise haftada 3 $(\% 58,8)$ sebze tükettiğini belirtmiştir. Annenin eğitim düzeyi ile meyve tüketimi ilişkisi incelendiğinde ise, annesi okuryazar olmayan katılımcıların \%42,9'u haftada 3 olmak üzere, haftada $1(\% 21,4)$ ve her gün $(\% 21,4)$ meyve tükettiği bildirilmiştir. Annesi okuryazar olan katılımcılar \%54 oranında her gün meyve tükettiği tespit edilmiştir. Annesi ortaokul ve üstü eğitim düzeyinde bulunan katılımcılar sırasıyla her gün $\% 58$ ve haftada $3 \% 29$ kez meyve tükettiğini belirtmiştir. Annesi lisans ve üstü eğitim düzeyinde bulunan katılımcıların $\% 52,4$ 'ü her gün $\% 28,6$ ’ s1 ise haftada 3 kere meyve tükettiğini bildirmişlerdir. Jones ve ark. (2011) İngiltere'de yaptı̆g çalışmada yüksek eğitim düzeyine sahip annelerin çocuklarının sebze meyve tüketim düzeyi daha yüksek olarak tespit edilmiştir. Borrmann ve diğ. (2015) yaptığ çalışmada; eğitim düzeyi yüksek ailelerin çocuklarında sebze meyve tüketiminin eğitim düzeyi düşük ailelerin çocuklarına göre anlamlı derecede yüksek olduğu belirlenmiştir. Ebeveynlerin eğitim seviyesinin yükselmesiyle ailenin sosyoekonomik düzeyindeki artışta birbiriyle ilişkili bulunmuştur. Valmórbidaa ve ark (2014) gerçekleştirdiği çalışmada sebze meye tüketimi ailelerin eğitim ve gelir düzeyi ile ilişkili olarak belirlenmiştir. Yapılan çalışmada; Tablo 5'de belirtildiği üzere anne eğitim düzeyi ortaokul ve üzerine doğru ilerledikçe meyve sebze tüketim oranlarında artış saptanmıştır. Eğitim seviyesi ile birlikte alım gücünün ve beslenme bilinç düzeyinin artışı bu sonuca sebep olarak gösterilebilir. 


\begin{tabular}{|c|c|c|c|c|c|c|}
\hline \multirow[b]{2}{*}{ Sebze } & \multicolumn{2}{|c|}{2000 TL ve altı } & \multicolumn{2}{|c|}{$2000-4000$ TL } & \multicolumn{2}{|c|}{4000 TL ve üzeri } \\
\hline & $\begin{array}{l}\text { Frekans } \\
\text { (n) }\end{array}$ & $\begin{array}{l}\text { Yüzde } \\
(\%)\end{array}$ & $\begin{array}{l}\text { Frekans } \\
\text { (n) }\end{array}$ & $\begin{array}{c}\text { Yüzde } \\
(\%)\end{array}$ & $\begin{array}{c}\text { Frekans } \\
\text { (n) }\end{array}$ & $\begin{array}{c}\text { Yüzde } \\
(\%)\end{array}$ \\
\hline Çiğ olarak & 54 & 80,6 & 59 & 77,6 & 26 & 55,3 \\
\hline $\begin{array}{l}\text { Pişmiş soğuk } \\
\text { yemek şeklinde }\end{array}$ & 23 & 34,3 & 29 & 38,2 & 30 & 63,8 \\
\hline Püre şeklinde & 5 & 7,5 & 12 & 15,8 & 11 & 23,4 \\
\hline $\begin{array}{l}\text { Yağda kızartılmış } \\
\text { şekilde }\end{array}$ & 33 & 49,3 & 31 & 40,8 & 16 & 34,0 \\
\hline $\begin{array}{l}\text { Taze sıkılmış } \\
\text { olarak }\end{array}$ & 19 & 28,4 & 11 & 14,5 & 3 & 6,4 \\
\hline \multirow[b]{2}{*}{ Meyve } & \multicolumn{2}{|c|}{2000 TL ve altı } & \multicolumn{2}{|c|}{$2000-4000$ TL } & \multicolumn{2}{|c|}{4000 TL ve üzeri } \\
\hline & $\begin{array}{l}\text { Frekans } \\
\text { (n) }\end{array}$ & $\begin{array}{c}\text { Yüzde } \\
(\%)\end{array}$ & $\begin{array}{l}\text { Frekans } \\
\text { (n) }\end{array}$ & $\begin{array}{c}\text { Yüzde } \\
(\%)\end{array}$ & $\begin{array}{c}\text { Frekans } \\
\text { (n) }\end{array}$ & $\begin{array}{c}\text { Yüzde } \\
(\%)\end{array}$ \\
\hline Taze meyve olarak & 65 & 97,0 & 73 & 96,1 & 45 & 95,7 \\
\hline $\begin{array}{l}\text { Kuru meyve } \\
\text { olarak }\end{array}$ & 9 & 13,4 & 11 & 14,5 & 20 & 42,6 \\
\hline $\begin{array}{l}\text { Taze sıkılmış } \\
\text { meyve suyu olarak }\end{array}$ & 19 & 28,4 & 27 & 35,5 & 19 & 40,4 \\
\hline $\begin{array}{l}\text { Hazır meyve suyu } \\
\text { olarak }\end{array}$ & 16 & 23,9 & 21 & 27,6 & 19 & 40,4 \\
\hline $\begin{array}{l}\text { Komposto veya } \\
\text { hoşaf olarak }\end{array}$ & 15 & 22,4 & 14 & 18,4 & 12 & 25,5 \\
\hline Tatlıların içinde & 12 & 17,9 & 14 & 18,4 & 22 & 46,8 \\
\hline
\end{tabular}

Sağlık Bakanlığı'nın 2014 raporuna göre; Türkiye'de sebze yemeklerinde (etli/etsiz) az veya çok suda pişirme/buğulama en çok kullanılan $(\% 79,4)$ yemek pişirme yöntemi olarak rapor edilmiştir. Çalışmamızda ise, Tablo 6'da SED'e göre sebzelerin nasıl tüketildikleri incelenmiştir. "2000 TL ve altı" gelir grubunda bulunan katılımcılar sebzeleri \%80,6 oranında çiğ olarak, \%49,3 oranında yağda kızartılmış şekilde ve \%34,3 oranında pişmiş soğuk yemek şeklinde tükettiklerini ifade etmiştir. "2000-4000 TL" gelir grubunda bulunan katılımcılar, sebzeleri sırasıyla, çiğ olarak $(\% 77,6)$, yağda kızartılmış $(\% 40,8)$ ve pişmiş soğuk yemek şeklinde $(\% 38,2)$ tükettiklerini bildirmişlerdir. "4000 TL ve üzeri”" gelir grubunda bulunan katılımcılar ise, $\% 63,8$ oranında pişmiş soğuk yemek, $\% 55,3$ oranında çiğ olarak ve \% 4,3 oranında yağda kızartılmış şekilde tükettiklerini ifade etmiş̧tir. Benzer bir şekilde; Tablo 6’da SED'e göre meyvelerin nası1 tüketildikleri incelenmiştir. Tabloya göre, "2000 TL ve altı" gelir grubunda bulunan katılımcılar meyveleri \%97 oranında taze olarak, \%28,4 oranında taze sıkılmış meyve suyu olarak ve $\% 23,9$ oranında hazır meyve suyu olarak tükettiklerini ifade etmiştir. "2000-4000 TL" gelir grubunda bulunan katılımcılar, meyveleri sırasıyla, taze olarak \%96,1 oranında, taze sıkılmış meyve suyu olarak $\% 35,5$ oranında ve hazır meyve suyu olarak $\% 27,6$ oranında tükettiklerini ifade etmiştir. " 4000 TL ve üzeri” gelir grubunda bulunan katııımcıların ise, \%95,7'si taze olarak, \%46,8'si tatlıların içinde, \%42,6'sı kuru meyve olarak, \%40,4' ü taze sıkılmış meyve suyu olarak ve \%40,4'ü hazır meyve suyu olarak tükettiklerini belirtmiştir. Giskes (2010) ve Darmon (2008)'in araştırmalarında Avrupa ve Amerika'da yapılan çalışmalarda, düşük SED'deki bireylerin daha çok kızartılmış sebze yemeklerini tercih ettikleri, yüksek SED'deki bireylerin ise daha çok çiğ sebze tüketmeyi tercih ettikleri bildirilmiştir. NHANES (2014) çalışması sonunda yayınlanan raporda 6-11 yaş arası katılımcılarda sebze tüketiminin yüzde 30'unu kızarmış patatesin oluşturduğu belirtilmiştir. Yazman (2016) çalışmasında ise ülkemizde yüksek ve düşük SED'de sebze en fazla etli veya kıymalı şekilde tüketilirken ikinci tercih olarak yüksek SED'de çiğ tüketim, düşük SED'de kızartılmış olarak tüketimdir. Katılımcıların meyveyi ise SED fark etmeksizin birinci sirada taze meyve şeklinde, ikinci sırada ise yüksek SED'dekilerin kuru meyve (\%25), DSED'dekilerin komposto/hoşaf (\%24,2) olarak tercih ettikleri gözlenmiştir. Gerçekleştirilen çalışmada Tablo 6'da gösterildiği üzere; düşük ve orta SED'de sebze en fazla çiğ (sırasıyla; \%80.6, \%77.6) olarak tüketilirken, ikinci sırada yağda kızartılmış (sırasıyla; \%49,3, \%40,8) şekilde, YSED'deki katılımcılarda ilk sırada pişmiş soğuk yemek şeklinde $(\% 63,8)$ ikinci sırada çiğ olarak $(\% 55,3)$ tükettikleri gözlendi. Aradaki farklılığın bireylerin beslenme bilinç düzeyi ile ilişkili olduğu düşünülmektedir. YSED' deki katılımcıların eğitim seviyelerinin de yükseleceği göz önünde bulundurulduğunda; beslenme bilinç düzeylerinin arttıkça kızartma yerine çiğ veya soğuk yemek olarak tüketimin artacağı düşünüllmektedir. Beslenme bilinç düzeyi ile ilgili daha fazla çalışmaya ihtiyaç vardır.

\section{Sonuç ve öneriler}

Beslenme alışkanlıklarının temeli çocukluk çağında oluşmaktadır. Oluşan alışkanlıkların genetik yönelendirmeler dışında en önemli çevresel faktörü ailedir. Ailenin tüketim alışkanlıkları çocukların beslenme alışkanlıkları için önemli bir rehberdir. Ailenin alışkanlıkları içinse alım gücü önemli bir kriterdir. Sağlıklı besinlerin doğru miktarda tüketilebilmesi için farklı ekonomik düzeylere uygun alternatif besin önerisi yaratılarak ailelere verilecek beslenme eğitimleri çocuklarının sağlıklı beslenme alışkanlıkları kazanması için önemli bir adım olabilir. 
Çocuk ve adölesanlara yönelik olarak hastalıklardan korunmada, kilo kontrolünü sağlamada yeterli ve dengeli beslenme açısından büyük rolü olan sebze ve meyvelerin tüketimini arttırmak için tanıtım kampanyalarında etkili ve sürdürülebilir stratejiler oluşturulmalıdır. 


\section{European Journal of Science and Technology}

\section{Kaynakça}

Ahmadi,N.,Black J.L.,Velazquez,C.E.,Chapman,G. E., ve Veenstra, G.,2014. Associations between socio-economic status and school-day dietary intake in a sample of grade 5-8 students in Vancouver, Canada. Public Health Nutrition 18(5): s:764-773,2014

Albani,V.,Butler,L.,Traill,B.W.,Kennedy,2017.Fruit and vegetable intake : with age across childhood and adolescence. British Journal of Nutrition11:s:759-765,2017

Aydın,K.,2011.Türkiye'de hanehalkı gıda harcamaları ve sosyoekonomik faktörler. Kocaeli Üniversitesi Sosyal Bilimler Enstitüsü Dergisi 21:s:56-76,2011

Bakanlığg1, T.C.S., 2015. Türkiye’ ye Özgü Beslenme Rehberi. Ankara,2015

Baysal,A.,2011.Beslenme.13.Baskı.Ankara:Hatiboğlu Yayınları.

Beaglehole R, Bonita R, Horton R, et al., 2011. Priority actions for the non-communicable disease crisis. Lancet377: s: 1438-47,2011

Bere,E.,Brug,J.,Klepp,K.,2007.Why do boys eat less fruit and vegetables than girls? Public Health Nutrition11:s:321-325,2007

Bere,E.,Lenthe,F.,Klepp,K.I.,Brug,J.,2008. Why do parents' education level and income affect the amount of fruits and vegetables adolescents eat?. European Journal of Public Health18:s:611-615,2008

Blanchette,L.,Brug,J., 2005. Determinants of fruit and vegetable consumption among 6-12-year-old children and effective interventions to increase consumption. Journal of Human Nutrition and Dietetics18:s:431-448,2005

Borrmann,A.,Mensink,B.M.,2015.Fruit and vegetable consumption by children and adolescents in Germany. Results of KİGGS-Welle 1.Bundesgesundheitsbl 58:s:1005-1014,2015

Çayır, A., Atak, N., Köse, S. 2011. Beslenme ve Diyet Kliniğine Başvuranlarda Obezite Durumu ve Etkili Faktörlerin Belirlenmesi Ankara Üniversitesi Tıp Fakültesi Mecmuası 64(1):s:13-19,2011

Chen TJ, Chen TJ, Modin B, Ji CY, Hjern A., 2011. Regional, socioeconomic and urban-rural disparities in child and adolescent obesity in China: a multilevel analysis. Acta Pediatr 100(12):s:1583-9,2011

Darmon N \& Drewnowski A, 2008. Does social class predict diet quality? Am J Clin Nutr 87:s: 1107-1117, 2008.

Diethelm,K.,Jankovic,N.,Moreno,LA., ve diğ.2012.Food intake of European adolescents in the light of different food-based dietary guidelines: results of the HELENA (Healthy Lifestyle in Europe by Nutrition in Adolescence) Study. Public Health Nutrition15:s:386398,2012

Ding,D.,Sallis,J.F.,Norman,G.J.,vediğ.2012. Community food environment, home food environment, and fruit and vegetable intake of children and adolescents.Journal of Nutrition Education and Behavior 44:s:634-638,2012

Dubowitz,T., Heron, M.,Finch,B.,ve diğ.,2008.Neighborhood socioeconomic status and fruit and vegetable intake among whites, blacks, and Mexican Americans in the United States. The American Journal of Clinical Nutrition 87:s:1883-1891,2008

Gibson,E.L.,Wardle,J.,Watts, C.J.,1998. Fruit and vegetable consumption, nutritional knowledge and beliefs in mothers and children.Appetite31:s:205-228,1998

Giskes,K.,Avendano,M.,Brug,J. ve diğ.,2010. A systematic review of studies on socioeconomic inequalities in dietary intakes associated with weight gain and overweight/ obesity conducted among European adults. Obesity Review 11:s:413-429,2010

Glasper A.,2010. The fat of the land: obesity prevention over obesity treatment. Br J Nurs;19(4):212-3,2010

Haynes-Maslow,L,.Parsons,S.E.,Wheeler,S.B.,Leone,L.A.,2013.Qualitative Study Of Perceived Barriers To Fruit And Vegetable Consumption Among Low-Income Populations, North Carolina.Prev Chronic Disease Journal 10:s:34-40,2013

Hughes,RJ.,Edwards,KL.ve diğ.,2012. Childhood consumption of fruit and vegetables across England: a study of 2306 6-7-year-olds. British journal of nutrition108:s:733-742,2012

Jafar TH, Qadri Z, Islam M, Hatcher J, Bhutta ZA, Chaturvedi N, 2008. Rise in childhood obesity with persistently high rates of undernutrition among urban school-aged Indo-Asian children. Arch Dis Child 93(5):s:373-378,2008

Jones,L.R.,Rogers,S.,Ness,A.R.2011.Emmett, Is maternal education level associated with diet in 10-year-old children?Public Health Nutrition14(11):s:2037-2048,2011

Kabaran,S.,Mercanlıgil,S.M.,2013.Adölesan dönem besin seçimlerini hangi faktörler etkiliyor. Güncel Pediatri Dergisi 11:s:121-127,2013

Kelly T, Yang W, Chen CS, et al.,2008. Global burden of obesity in 2005 and projections to 2030. Int J Obes (Lond) 32:s:1431-7,2008

Kim,S.A.,Moore,L.V., Galuska, D.,ve diğ.,2014. Division of nutrition, physical activity, and obesity, National Center for Chronic Disease Prevention and Health Promotion, CDC.

Larson,N.,Laska,M.N.,Story,M.,Neumark-Sztainer,D.,2012.Predictors of fruit and vegetable intake in young adulthood.J Acad Nutr Diet 112:s:1216-1222,2012

Larson,N.I.,Neumark-Sztainer,D.,Harnack, L., Wall, M., Story, M.,Eisenberg, M. E.,2009.Calcium and dairy intake. Longitudinal trends during the transition to young adulthood and correlates of calcium intake. Journal of Nutrition Education and Behavior 41:s:254260,2009

Liem,D.,G.,Bogers,R.P.,Dagnelie,P.C.,Graaf,C.,2006.Fruit Consumption of Boys (8-11 Years) is Related to Preferences for Sour Taste.Appetite 46: s:93-96,2006

Molaison,E.F.,Connell,C.L.,Stuff,J.E.,Yadrick,M.K.,Bogle, M., 2005. Influences on fruit and vegetable consumption by low-income black American adolescents. Journal of Nutrition Education and Behavior 37:s:246-251,2005

Neumark,D.,Flattum, C.F., Story,M.,Feldman,S.,Petrich,C.A.,2008. Dietary approaches to healthy weight management for adolescents: the New Moves model. Adolesc Med State Art Rev19:s: 421-430,2008

Ogden CL, Carroll MD, Lawman HG, Fryar CD, Kruszon-Moran D, Kit BK, Flegal KM.,2016. Trends in Obesity Prevalence Among Children 1988-1994 Through 2013-2014. JAMA315(21):s:2292-2299,2016

Pedersen,T.P.,Meilstrup,C.,Holstein,B.E.,\&Rasmussen,M.,2011.Fruit and vegetable intake is associated with frequency of breakfast, lunch and evening meal. Cross-sectional study of 11-, 13-, and 15-year-olds. International Journal of Behavioral Nutrition and Physical 
Activity9:s:9-15,2011

Avrupa Bilim ve Teknoloji Dergisi

Perikkou,A.,Gavrieli,A.,Tzirkali,M.,Yannakoulia,M.,2013.A novel approach for increasing fruit consumption in children. Journal Of The Academy Of Nutrition And Dietetics113(9):s:1188-193,2013

Sağlık Bakanlığı Türkiye Beslenme ve Sağlık Araştırması 2010. Beslenme Durumu ve Alışkanlıklarının Değerlendirilmesi Sonuç Raporu. 2014

Serdula MK, Ivery D, Coates RJ, et al.,1993. Do obese children become obese adults? A review of the literature. Prev Med 22:s: 16777,1993

Şimşek,I.,Yabancı,N.,Turan,Ş.,2009.Okul çağı çocuklarının beslenme çantalarının değerlendirilmesi.Aile ve Toplum Dergisi 5(19):s:99110,2009

Thompson,D.,Ferry,R., ve diğ.,2016. Improvement in Fruit and Vegetable Consumption Associated with More Favorable Energy Density and Nutrient and Food Group Intake,but not Kilocalories.Journal Of The Academy Of Nutrition And Dietetics (4): s:1443-1449,2016

Türkiye Cumhuriyeti Sağlık Bakanlığı Temel Sağlık Hizmetleri Genel Müdürlüğü.2011. Türkiye’de Okul Çağı Çocuklarında (6-10 Yaş Grubu) Büyümenin İzlenmesi (TOÇBİ) Projesi Araştırma Raporu. Ankara.

Türkiye Cumhuriyeti Sağlık Bakanlığı.2014.Beslenme Durumu ve Alışkanlıklarının Değerlendirilmesi Sonuç Raporu. Ankara.

Uçar,A.,Çakıroğlu,P.F.,2012.Farklı sosyoekonomik düzeye sahip ilköğretim öğrencilerinin meyve tüketimleri. Ankara Sağlık Bilimleri Dergisi 1(1):s:91-103,2012

Valmórbidaa,J.L.,Vitolo,M.R.,2014. Factors associated with low consumption of fruits and vegetables by preschoolers of low socioeconomic level. Journal of Pediatrics90(152):s:464-471,2014

Van Jaarsveld CHM, et al., 2015.Childhood obesity trends from primary care electronic health records in England between 1994 and 2013 : population-based cohort study. Arch Dis Child 4:s:1-6,2015

Vereecken,C., ve diğ.,2015.Fruit and vegetable consumption trends among adolescents from 2002 to 2010 in 33 countries.European Journal of Public Health25(2):s:16-21,2015

Von Post-Skagegard,M.,Samuelson,G.,Karlstrom,B.,ve diğ.,2002.Changes in food habits in healthy Swedish adolescents during the transition from adolescence to adulthood. European Journal of Clinical Nutrition56:s:532-538,2002

WHO,2012. Population-based approaches to Chıldhood Obesity Preventıon ,2012

Wolnıcka,K.,Taraszewska,A.M.,Schuets,J.,Jarosz,M.,2015.Factors within the family environment suck as parent dietary hobits and fruit and vegetable availability have the greatest influence on fruit and vegetable consumption by polish children. Public Healty Nutrition 18(15):s:2705-2711,2015

Yazman,H.,2016.Farklı sosyoekonomik düzeydeki 10-14 yaş grubu çocuklarda sebze-meyve tüketim alışkanlığının incelenmesi. Yüksek Lisans Tezi. İstanbul: Medipol Üniversitesi SBF. 